ELECTRICAL MACHINE DYNAMICS 


\section{ELECTRICAL MACHINE DYNAMICS}

D. P. SEN GUPTA

Department of Electrical Engineering

The Indian Institute of Science

Bangalore

India

and

J. W. LYNN

Formerly

Department of Electrical Engineering and Electronics

The University of Liverpool

Liverpool

England

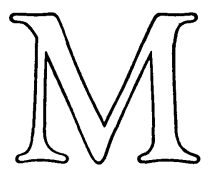


(C) D. P. Sen Gupta and J. W. Lynn 1980

Softcover reprint of the hardcover 1st edition 1980 978-0-333-13884-7

All rights reserved. No part of this publication may be reproduced or transmitted, in any form or by any means, without permission

First published 1980 by

THE MACMILLAN PRESS LTD

London and Basingstoke

Associated companies in Delhi Dublin

Hong Kong Johannesburg Lagos Melbourne

New York Singapore and Tokyo

British Library Cataloguing in Publication Data

Sen Gupta, Debi Prasad

Electrical machine dynamics.

1. Electric machinery-Dynamics

I. Title II. Lynn, John Williamson

621.31'042 TK2189

ISBN 978-1-349-01617-4 ISBN 978-1-349-01615-0 (eBook)

DOI 10.1007/978-1-349-01615-0

This book is sold subject to the standard conditions of the Net Book Agreement 


\section{Contents}

Preface xi

1 INTRODUCTION 1

1.1 Electrical Machines 1

1.2 Dynamic Stability 5

1.3 Generalised Machine Theory 6

1.4 Reference 7

2 A REVIEW OF BASIC MACHINE THEORY 8

2.1 Introduction 8

2.2 Inductive Coupling 9

2.3 Self-inductance 9

2.3.1 Calculation of self-inductance $\quad 12$

2.4 Electromechanical Analogy 13

2.5 Magnetic Saturation 15

2.6 Stored Energy 15

2.7 Coupled Circuits 20

2.8 Generated Voltage 25

2.9 The Stationary Observer 27

2.10 Actual Machines 29

2.11 Electric Motor Operation 30

2.12 Rotating Field Theory 31

2.12.1 Operation of an induction motor 34

2.12.2 Operation of a synchronous motor $\quad 35$

2.13 Steady-state Equations of d.c. Machines 35

2.13.1 The load characteristic of d.c. generators 38

2.14 Motor Characteristics 41

2.14.1 Shunt motor 41

2.14.2 Compound motor $\quad 42$

2.14.3 Series motor $\quad 43$

2.15 Synchronous Machines 43 
2.15.1 The m.m.f. and flux density waves 44

2.15.2 The effects of non-uniform air gap 45

$\begin{array}{lll}2.15 .3 & \text { Amortisseur windings } & 47\end{array}$

2.15.4 Methods of field excitation $\quad 48$

2.15.5 Mode of operation $\quad 48$

$\begin{array}{lll}2.15 .6 & \text { Vector diagram } & 49\end{array}$

2.15.7 Generator and motor operation $\quad 50$

2.15.8 Active and reactive power 51

2.15.9 Expression for reactive power $\quad 52$

2.15.10 Power-angle characteristic $\quad 52$

2.16 Effect of a Voltage Regulator $\quad 55$

2.17 Induction Motor $\quad 56$

$\begin{array}{lll}2.17 .1 & \text { Equivalent circuit } & 56\end{array}$

2.17.2 Calculation of torque from equivalent circuit 58

$\begin{array}{lll}2.18 & \text { References } & 60\end{array}$

3 ELECTRODYNAMICAL EQUATIONS AND THEIR
SOLUTION

3.1 A Spring and Plunger System $\quad 61$

$\begin{array}{ll}3.2 & \text { Rotational Motion } \\ 3.3 & 63\end{array}$

3.3 Mutually Coupled Coils $\quad 65$

$\begin{array}{lll}3.4 & \text { Lagrange's Equation } & 66\end{array}$

3.4.1 Application of Lagrange's equation to electromechanical systems $\quad 69$

3.5 Solution of the Electrodynamical Equations 74

$\begin{array}{lll}\text { 3.5.1 Euler's method } & 74\end{array}$

$\begin{array}{ll}\text { 3.5.2 Runge-Kutta method } & 75\end{array}$

$\begin{array}{ll}\text { 3.6 Solving a Spring and Plunger Problem } & 77\end{array}$

3.7 Linearisation of the Dynamic Equations 82

$\begin{array}{lll}\text { 3.7.1 Routh-Hurwitz criterion } & 84\end{array}$

$\begin{array}{lll}3.8 & \text { Reference } & 86\end{array}$

4 ELECTRICAL MACHINE DYNAMICS 87

$\begin{array}{lll}4.1 & \text { Introduction } & 87\end{array}$

4.2 Dynamics of d.c. Machines 88

4.2.1 Separately excited d.c. motor $\quad 88$

4.2.2 Laplace transform method 90

$\begin{array}{lll}4.2 .3 & \text { State variables } & 92\end{array}$

$\begin{array}{lll}\text { 4.2.4 Transient solution } & 93\end{array}$

$\begin{array}{ll}\text { 4.2.5 Series excited d.c. machine } & 95\end{array}$

4.3 Induction Motor 98

4.3.1 Determination of acceleration: Method I 98

4.3.2 Determination of acceleration: Method II 99

$\begin{array}{lll}4.4 & \text { The Alternator } & 104\end{array}$

4.4.1 Electrical transients 105

$\begin{array}{ll}\text { 4.4.2 The dynamics of the system } & 107\end{array}$

$\begin{array}{lll}4.5 & \text { References } & 115\end{array}$ 
5.1 The Generalised Machine Concept 116

5.2 The Primitive Machine 117

5.3 The Induction Motor and the Primitive Machine 120 $\begin{array}{ll}\text { 5.3.1 Slip-ring references axes } & 121\end{array}$

5.4 Primitive Form of Various Machines 121

5.5 Primitive Machine Equations along Stationary Axes 123 5.5.1 Flux linkages 123

$\begin{array}{lll}5.6 & \text { Stator and Rotor Voltage Equations } & 124\end{array}$

$\begin{array}{ll}\text { 5.6.1 The torque equation } & 130\end{array}$

5.7 Transformation of Reference Frames 132

5.7.1 Matrix transformations 133

5.7.2 An electrical circuit 136

5.8 The d.c. Machine 139

5.9 The Induction Motor 142

5.10 Representation of the Transient Equations in
State-variable form

5.11 Nonlinearities in Machine Equations 149

$\begin{array}{lll}5.11 .1 & \text { Saturation } & 149\end{array}$

5.11.2 Commutation 151

5.11.3 Space harmonics 151

5.12 Machine torque expressions 152

5.12.1 The separately excited d.c. motor 152

5.12.2 The induction motor 153

5.12.3 The synchronous machine 155

5.13 References 156

6 ELECTRICAL MACHINE DYNAMICS continued 157

6.1 Introduction 157

6.2 Basic Machine Electrodynamics 157

6.3 Interconnected Machines 158

6.4 The Alternator/Induction Motor 159

6.4.1 The primitive machine 162

$\begin{array}{ll}\text { 6.4.2 The alternator } & 162\end{array}$

6.4.3 The alternator in steady state 163

$\begin{array}{ll}\text { 6.4.4 The induction motor } & 163\end{array}$

$\begin{array}{ll}\text { 6.4.5 Alternator equations for transient } & \\ \text { performance } & 164\end{array}$

6.4.6 Equations for dynamical response of the induction motor 165

6.5 Interconnected Machine $C$-Matrices 169

6.5.1 The d.c. generator and motor 171

6.5.2 An alternator supplying a synchronous motor $\quad 175$

6.6 The Ward-Leonard System 177

6.6.1 The machine matrices 181

$\begin{array}{ll}\text { 6.6.2 The system equations } & 182\end{array}$

$\begin{array}{lll}\text { 6.6.3 Nonlinearities } & 184\end{array}$ 
6.6.4 Steady-state tests

$\begin{array}{lll}\text { 6.6.5 Transient analysis } & 189\end{array}$

6.6.6 Laboratory tests 192

$\begin{array}{lll}6.7 & \text { Power System Dynamics } & 196\end{array}$

6.8 Small Perturbations (Hunting) 199

$\begin{array}{lll}6.9 \text { References } & 202\end{array}$

7 SMALL OSCILLATIONS 203

$\begin{array}{lll}7.1 \text { Introduction } & 203\end{array}$

7.2 Synchronous Machine Equation during Small Oscillations $\quad 204$

7.3 General Equations for Small Oscillations 206

7.4 Representation of the Oscillation Equations in $\begin{array}{ll}\text { State-variable Form } & 207\end{array}$

$\begin{array}{lll}\text { 7.4.1 Bocher's formula } & 208\end{array}$

7.5 The Characteristic Equation of a d.c. Generator

7.6 Damping and Synchronising Torques in Stability

\begin{tabular}{ll} 
Analysis & 212 \\
\hline
\end{tabular}

$\begin{array}{lll}\text { 7.6.1 An experimental system } & 217\end{array}$

7.6.2 Computation of the synchronising and damping
torque coefficients

$\begin{array}{lll}\text { 7.6.3 Effect of a voltage regulator } & 225\end{array}$

7.7 Hunting Analysis of Interconnected Machines 231

$\begin{array}{ll}\text { 7.7.1 Ward-Leonard machines } & 231\end{array}$

$\begin{array}{ll}\text { 7.7.2 Interconnected machines } & 235\end{array}$

$\begin{array}{ll}\text { 7.7.3 Computation and test results } & 236\end{array}$

$\begin{array}{lll}7.8 \text { References } & 242\end{array}$

8 SYNCHRONOUS MACHINE OSCILLATIONS 244

$\begin{array}{lll}8.1 \text { Introduction } & 244\end{array}$

8.2 Absolute and Apparent Changes in Current
and Voltage Vectors

8.3 Transformation to Kron's Freely Rotating

$\begin{array}{lll}8.4 & \text { Equivalent Networks } & 255\end{array}$

8.4.1 Hunting network in Park's axes 259

8.4.2 Hunting network in Kron's axes 262

$\begin{array}{ll}\text { 8.4.3 Numerical examples } & 266\end{array}$

$\begin{array}{ll}\text { 8.4.4 The effect of a voltage regulator } & 270\end{array}$

$\begin{array}{lll}8.5 & \text { References } & 275\end{array}$

\section{APPENDIXES}

Al PER-UNIT NOTATION 277

$\begin{array}{lll}\text { A1.1 Transformers } & 277\end{array}$

$\begin{array}{lll}\text { A1.2 Fault Calculations } & 279\end{array}$

A1.3 Direct Current Machines 281 
$\begin{array}{lll}\text { A1.4 Alternator Parameters } & 281\end{array}$

A1.5 The Inertia Constant 282

$\begin{array}{ll}\text { A2 MEASUREMENT OF MACHINE } & 287 \\ \text { PARAMETERS } & 282\end{array}$

$\begin{array}{lll}\text { A2.1 The Induction Motor } & 287\end{array}$

A2.2 The Synchronous Machine 288

A2.3 Direct Current Machines 292

A2.4 The Polar Moment of Inertia and the

A2.5 Measurement of Synchronous Load Angle $\delta \quad 293$

A3 ESTIMATION OF ALTERNATOR PARAMETERS

USING THE EQUIVALENT

CIRCUITS FOR DIRECT AND

QUADRATURE AXES

Index 


\section{Preface}

The book is designed to give a straightforward, logical presentation of the methods available for predicting the dynamic behaviour and response of electrical machines. Three particular aspects of machine theory have been utilised to achieve this.

1. The early chapters contain a simple presentation of electromagnetic theory underlying the concepts of self and mutual inductance in saturable machines containing several windings.

2. The generalised form of electrical machine theory is developed in simple matrix terms. The d.c. machines, induction motor and alternator are treated in detail. Extension to other types of machines not treated in the book is straightforward.

3. A torque-balance analysis of machines is presented, from which the dynamic response and the synchronising and damping forces can be investigated and computed. The effect of a generator voltage regulator is introduced and its influence on power system dynamic response is discussed.

The material is developed to the level of final year honours undergraduate and first year post-graduate students in electrical engineering. The authors also had in mind power system engineers concerned with the design, performance and control of turbo-alternators and large salient-pole generators for hydroelectric schemes, together with ancillary electrical drives, and mechanical engineers concerned with industrial electrical machine systems.

In presenting the dynamical analysis of electrical machine systems, the authors are very conscious that a vast amount of important machine theory has been taken for granted, or only very briefly discussed in the text. The book is clearly based on the work of three or four generations of outstanding electrical machine engineers who provided industry with a wide variety of convenient, easily controlled and highly efficient drive systems. Names such as Miles 
Walker, Say, Gibbs, Adkins, Concordia, Park, Alger and Kron, to mention only a few well known to students, span both post-war and pre-war technologies. The authors hope that the present book may make a contribution to the dynamical aspects of machine and power system engineering.

They wish to express their thanks to their former colleagues, Drs C. V. Jones and B. W. Hogg for continuing interest and discussion. They are very much indebted to past research students who carried out the experimental work and computation for virtually all of the results presented here. Dr M. Y. M. Yau developed the earlier work on regulator effects in Chapters 7 and 8 , in the laboratories at the University of Liverpool, and the more recent work was done by $\mathrm{Mr}$ N. G. Narahari at the Indian Institute of Science, Bangalore. The electromechanical studies using the alternator and induction motor in the laboratory were carried out by Dr J. S. Gorley and the Ward-Leonard system dynamics by Dr M. W. Main, both at that time at the University of Liverpool. The latter experiments were suggested by Mr H. J. T. Whitehead and Mr J. Warnock of B. N. F. L. Windscale in discussions on power system dynamics and the authors wish to acknowledge the valuable insight into practical power system dynamic problems which emerged from these talks.

Mrs Joan Johnston carefully and patiently typed the manuscript and her assistance throughout is gratefully acknowledged. The authors wish to express their thanks to Mr Malcolm Stewart and Mr Richard Powell of The Macmillan Press Ltd for their guidance at all stages in the preparation of the manuscript. 